\title{
D. Francisco de Aquino Corrêa e a construção da identidade mato-grossense
}

\section{Francisco de Aquino Corrêa and the construction of the mato-grossense identity}

Jérri Roberto Marin*

\begin{abstract}
Resumo
Apresenta-se neste artigo o papel desempenhado pelo bispo e arcebispo de Cuiabá D. Francisco de Aquino Corrêa na construção da identidade mato-grossense, entre as décadas de 1910 a 1930. Como governador de Mato Grosso, interveio na esfera cultural a fim de fortalecer as elites cuiabanas e superar as crises política, econômica e social. Para tal, arregimentou um grupo de intelectuais que se empenharam na construção da identidade regional assentada na idealização das terras e do homem mato-grossense, superando os estigmas de fronteira-sertão. Para tal, criou o Instituto Histórico e Geográfico de Mato Grosso e a Academia Mato-grossense de Letras, símbolos regionais (hino e brasão), e realizou sucessivas manifestações culturais. Como membro da hierarquia eclesiástica, empenhou-se em recuperar o prestígio da Igreja Católica, valorizar os aspectos religiosos da cultura brasileira e propagar o regionalismo, o nacionalismo e o culto à nação.
\end{abstract}

Palavras-chave: D. Francisco de Aquino Corrêa; Mato Grosso; Instituto Histórico e Geográfico de Mato Grosso; Identidade.

\begin{abstract}
This article analyzes the role played by the bishop and archbishop of Cuiabá D. Francisco de Aquino Corrêa in the construction of Mato Grosso's identity between the 1910s and 1930s. As governor of Mato Grosso, he intervened in the cultural sphere in order to strengthen the elite of Cuiabá and overcome political, economic and social crises. To this end, he recruted a group of intellectuals who worked to build a regional identity based on the idealization of the land and the men from Mato Grosso, overcoming the frontier-backwoods stigma. To this end, he created the Historical and Geographical Institute of Mato Grosso and the Mato Grosso Academy of Letters, regional symbols (hymn and coat of arms) and held successive cultural events. As a member of the ecclesiastical hierarchy, he endeavored to restore the prestige of the Catholic Church, to value the religious aspects of brazilian culture and to propagate regionalism, nationalism and cult of the nation.
\end{abstract}

Keywords: D. Francisco de Aquino Corrêa; Mato Grosso; Historical and Geographical Institute of Mato Grosso; Identity.

Artigo recebido em 31 de julho de 2017 e aprovado em 28 de agosto de 2018.

* Doutor em História pela Universidade Estadual Paulista (UNESP). Professor Titular da Universidade Federal de Mato Grosso do Sul (UFMS/Brasil). País de origem: Brasil. E-mail: jerrimarin@bol.com.br

Horizonte, Belo Horizonte, v. 16, n. 50, p. 780-811, maio/ago. 2018 - ISSN 2175-5841 


\section{Introdução}

O artigo analisa o papel desempenhado por D. Francisco de Aquino Corrêa na construção da identidade mato-grossense, no período em que foi bispo (19141922) e arcebispo (após 1922) de Cuiabá e governador de Mato Grosso (1918-1922). Pretende-se identificar, em suas ações e em seus discursos, aspectos de ordem política, simbólico-ideológica e do imaginário cujo objetivo era criar sentidos de regionalidade e de nacionalidade para superar os estigmas atribuídos a Mato Grosso como fronteira-sertão.

D. Francisco de Aquino Corrêa nasceu em 2 de abril de 1885, numa das famílias mais tradicionais de Cuiabá. Em 1902, com 17 anos, ingressou na Congregação Salesiana e prosseguiu seus estudos no Noviciado do Coxipó da Ponte. Em 1904, foi enviado a Roma, onde estudou Filosofia e Teologia, na Academia de São Tomáz Angelicum e na Pontifícia Universidade Gregoriana, respectivamente. Em ambas foi titulado doutor, com o distintivo Summa Cum Laude. Em 17 de janeiro de 1909, foi ordenado padre em Roma e, em 1910, retornou para Mato Grosso e tornou-se professor no Liceu Salesiano São Gonçalo. Posteriormente, em 2 de abril de 1914, o Papa Pio X o elevou à dignidade episcopal, como bispo de Prusiade e auxiliar de D. Carlos Luiz D’Amour. Segundo o Núncio Apostólico Giuseppe Aversa, suas qualidades intelectuais e morais eram excepcionais, apesar de ter apenas 29 anos. ${ }^{1}$

Em 1917, com a renúncia do bispo de Corumbá, D. Cirilo de Paula Freitas, D. Aquino foi nomeado administrador apostólico. Porém, com a intervenção do presidente Venceslau Brás em Mato Grosso, em 10 de janeiro de 1917, foi indicado para ser governador para o mandato de 1918 a 1922. Com o falecimento de D. Carlos, em 9 de julho de 1921, foi nomeado arcebispo de Cuiabá, assumindo o posto no dia 16 de abril de 1922. Entre as virtudes destacadas pelo Núncio Apostólico

\footnotetext{
${ }^{1}$ Archivio Segreto Vaticano. Indici 1153, Fondo della Nunziatura Apostolica in Brasile, Busta 171, Fascicolo 931. Carta de Enrico Gasparri para Gaetano De Lai Enrico Gasparri, de 19 jul. 1921.
}

Horizonte, Belo Horizonte, v. 16, n. 50, p. 780-811, maio/ago. 2018 - ISSN 2175-5841 
Enrico Gasparri, estava o seu "espírito patriótico", qualidade importante no contexto da ofensiva católica de aproximação com o regime republicano e de cristianização da sociedade brasileira. ${ }^{2}$ Sua gestão como arcebispo durou 34 anos, entre os anos de 1922 e 1956.

A formação e consolidação intelectual de D. Aquino foram marcadas pelos contextos de ofensiva da Igreja Católica na sociedade. Suas matrizes políticas eram os postulados da Santa Sé, que defendia o corporativismo, uma "terceira via”, em contraposição ao socialismo, ao comunismo, à democracia e ao capitalismo liberal. 3 A sociedade era concebida como um todo orgânico, sendo ele o Estado, a Nação, a Igreja Católica, nele integrando o indivíduo, que deveria obedecer às autoridades e colaborar para que houvesse o equilíbrio e a harmonia absolutos. No Brasil, filiavase ao Movimento de Restauração da Sociedade Nacional em Cristo, conhecido como Idade Nova ou Neocristandade, liderado por D. Sebastião Leme da Silveira Cintra. Ou seja, estava comprometido em superar as crises da civilização burguesa, em regenerar o Brasil, a política e o Estado, por meio da religião, e em unir os brasileiros em torno de um projeto coletivo a favor do progresso espiritual e material.

Nesse contexto, D. Aquino procurava disseminar os pontos de vista da Igreja Católica. Ao se inserir na vida cultural brasileira, defendia o regionalismo e o nacionalismo, reafirmava a tradição católica do país e condenava os movimentos sociais e o modernismo literário. Como decorrência, tornou-se um dos porta-vozes do conservadorismo em voga no Brasil.4

\footnotetext{
${ }^{2}$ Archivo Secreto do Vaticano, Indice 1289, Congregazione Consitoriale, Positiones, Brasile 1, dal 678/1910 al 503/1921. Prot. N. 16/1914 Cerca: Provvista di alcune sedi, 22 Gennaio 1914, p. 20-26.

${ }^{3}$ O corporativismo foi defendido nas encíclicas Rerum Novarum (1891), por Leão XIII, e na Quadragesimo Anno (1931), por Pio XI.

${ }^{4}$ As ideias conservadoras provêm do movimento intelectual que recusou as propostas iluministas, os ideais da Revolução Francesa e os projetos da modernidade. No campo político, eram contrários a democracia, ao pensamento de esquerda, a igualdade de gêneros e as mudanças na estrutura da governabilidade que pudessem atingir o tradicionalismo e o autoritarismo. No campo social, defendiam a família, os princípios religiosos e morais e a manutenção das tradições culturais católicas (CANTO-SPERBER, 2000, p. 98).
}

Horizonte, Belo Horizonte, v. 16, n. 50, p. 780-811, maio/ago. 2018 - ISSN 2175-5841 


\section{D. Aquino e a construção da identidade mato-grossense}

Inúmeras imagens estereotipadas sobre Mato Grosso eram difundidas no Brasil e no exterior, como, por exemplo, de que a região era uma fronteira-sertão, compreendida como outro espaço geográfico, simbólico e social. Seria um lugar insalubre, de atraso técnico, de comportamentos antigos, de alto índice de criminalidade e de violência, de natureza virgem e indomável e de negação da cultura, da civilização e da nacionalidade (GALETTI, 2000). Seria um "mundão" abandonado, terras que não se acabavam. As impressões variavam de acordo com as situações às quais os viajantes estavam submetidos. Esse "mundão" podia ser visto do ponto de vista ora de uma natureza idílica e edênica, aproximando-se do imaginário do paraíso terrestre; ora de uma natureza exótica, selvagem, indômita, inóspita, perigosa, intransponível, que parecia não conhecer limites geográficos. Mato Grosso era também o lugar do atraso econômico, apesar de ser uma região abundante em recursos naturais. O homem mato-grossense foi, na maioria das vezes, visto a partir de olhares negativos: o grande número de indígenas aproximava Mato Grosso da barbárie e as populações mestiças seriam inferiores racialmente e pertenceriam aos primeiros estágios evolutivos da humanidade. Dessa forma, a região necessitava de uma urgente ação civilizatória.

Essas imagens negativas geravam um profundo constrangimento, mal-estar e revolta em face de uma identidade estigmatizada pela barbárie (GALETTI, 2000, p. 33). Segundo Bourdieu (1989, p. 125), o "estigma produz a revolta contra o estigma", dando "à revolta regionalista ou nacionalista, não só as suas determinantes simbólicas mas também os seus fundamentos econômicos e sociais, princípios de unificação do grupo", impelindo-os à ação e à mobilização. Como reação à estigmatização, houve esforços para alterar a sua definição.

Em 1904, por exemplo, foi elaborado para a Exposição Internacional de Saint Louis, nos Estados Unidos, um folheto com informações detalhadas sobre a região. Nesse mesmo ano, foram criadas as revistas O Arquivo e Matto-Grosso, que 
dedicavam seções sobre a história de Mato Grosso, fomentando a produção historiográfica regional. Em 1905, foi elaborado um folheto em língua inglesa para divulgar as potencialidades econômicas da região. Em 1908, houve a participação na Exposição Nacional; em 1912, na Exposição Nacional da Borracha, ambas realizadas no Rio de Janeiro; e, em 1913, em uma exposição em Nova York. Um dos projetos mais elaborados foi a publicação do Álbum Gráfico do Estado de MattoGrosso, que foi publicado em 1914 e que "trazia um mapeamento completo dos rios, solos, clima, dimensões territoriais, meios de transporte, atividades econômicas, população e de muitos outros aspectos da geografia física e social de Mato Grosso" (GALETTI, 2000, p. 262). O objetivo do álbum era "apresentar o Matto-Grosso moderno aos que, dentro e fora do Brasil, não o conhecem e desejam conhece-lo". Segundo os editores, a publicação “contribuirá para a evolução da vida econômica do Estado", a fim de atrair investimentos e imigrantes (AYALA, 1914, p. 1). Essas publicações, em seu conjunto, procuravam redefinir a identidade, ao construir a imagem de um povo, ao eleger aspectos comuns, tais como tradições, crenças, valores, mitos, heróis e fatos históricos. O álbum, por sua vez, instituiu os principais parâmetros a partir dos quais foi elaborada a identidade regional (ZORZATTO, 2000, p. 429). Os discursos regionalistas "produzem estratégias e práticas sociais, que [...] tendem a impor uma autoridade à custa de outras, por elas menosprezadas, a legitimar um projeto reformador ou a justificar, para os próprios indivíduos as suas escolhas ou condutas" (CHARTIER, 1988, p. 17).

Nesse contexto de redefinição identitária, os discursos de modernização, civilização e progresso ganhavam respaldo com a difusão em Mato Grosso de instituições de ensino, de gráficas, de observatórios meteorológicos, de missões religiosas entre as populações indígenas e do incremento econômico e demográfico. A difusão de inovações tecnológicas, tais como a navegação a vapor, o telégrafo e a ferrovia Noroeste do Brasil, diminuiu as distâncias, facilitou as comunicações e inseriu a região num mercado de bens, de consumo e de circulação em nível internacional. Porém, as disputas entre as facções pelo controle do poder no âmbito estadual geraram uma sucessão de crises políticas que reforçavam os estigmas.

Horizonte, Belo Horizonte, v. 16, n. 50, p. 780-811, maio/ago. 2018 - ISSN 2175-5841 
Em virtude dessas instabilidades, em 1917, o presidente Venceslau Brás decretou uma intervenção, quando foi realizado um acordo de conciliação com os partidos políticos locais: o Partido Republicano MatoGrossense (PRMG), dirigido por Pedro Celestino Correia da Costa, e o Partido Republicano Conservador (PRC), liderado pelo senador Antônio Azeredo, sendo nomeado como governador para o mandato de 1918 a 1922 o bispo D. Aquino Francisco Corrêa. A indicação foi legitimada em torno das ideias de conciliação, paz, unidade e fim dos conflitos políticos e de uma nova era de progresso e civilização. A Santa Sé anuiu e o exonerou dos cargos de administrador apostólico de Corumbá e de auxiliar de D. Carlos. Sua missão seria a de redentor e de restaurador, pois Deus a teria confiado para que pacificasse Mato Grosso e normalizasse a ordem social e política. Ele pretendia construir um governo de união e pacificação a fim de garantir a governabilidade.

No discurso de posse, o bispo afirmou que tinha ocorrido em Mato Grosso uma “catastrophe que abalára até a estrutura mais íntima e essencial do Estado, destruindo aquelles mesmos poderes, que [formavam], por assim dizermos, as columnas graniticas da sua constituição política”, sendo necessário "que uma nova e poderosa voz repita a solenne palavra creadora: Fiat lux! Faça-se a luz! De que carecemos: Lex lux" (CORRÊA, 1918). A principal preocupação era construir um governo de conciliação e um novo projeto político que fosse capaz de assegurar o equilíbrio entre os partidos e o desenvolvimento econômico regional. A nova ordem política pretendia construir, por meio da colaboração de todos, um futuro pacífico, harmonioso, próspero e moderno. As mensagens de paz e de tranquilidade, que D. Aquino disseminava, subordinavam a política à moral e conciliava a ordem com o progresso, em benefício da coletividade. Apesar da forte oposição, o bispogovernador conseguiu concluir o mandato, ao contrário dos seus antecessores, e estabelecer um acordo de paz entre os dois partidos políticos.

A intervenção do Estado na produção artística e cultural advinha da sua função na esfera política, na construção tanto do regionalismo como da harmonia 
social. Para D. Aquino, as divisões partidárias e as lutas fraticidas entre as facções políticas ameaçavam a unidade do Estado e do povo e inviabilizavam seu desenvolvimento econômico. O objetivo era superar esses males e formar um novo ordenamento da sociedade, a fim de superar as crises políticas e unir as elites e a sociedade num projeto para garantir a estabilidade social e política e o desenvolvimento regional. Para tal, investiu na realização de alianças políticodoutrinárias com as elites favoráveis às suas pretensões, pois estas estavam cientes da colaboração ideológica eficaz que a Igreja Católica estava em condições de prestar à consolidação da nova ordem social e política.

Nesse contexto, havia inúmeros intelectuais preocupados em pesquisar e escrever sobre a região e em redefinir a identidade regional, tais como Estevão de Mendonça, Antônio Fernandes de Souza, Virgílio Alves Corrêa Filho, João Barbosa de Faria, Philogonio de Paula Corrêa, José Barnabé de Mesquita, entre outros. Esses intelectuais tornaram-se colaboradores de D. Aquino e muitos passaram a ocupar postos importantes no governo estadual.

Durante sua gestão, foram promovidas "peças teatrais, concertos musicais, almoços e jantares”, envolvendo políticos e cidadãos comuns, cujo fim era “conseguir favores e privilégios junto ao governo" e expressar "o reconhecimento da liderança de D. Aquino, a crença em sua neutralidade frente ao jogo político, a confiança em sua postura paternal de religioso e a esperança de que seu governo pudesse [...] significar melhores dias para Mato Grosso” (GALETTI, 2000, p. 278). Ele investiu também em sucessivos empreendimentos culturais e em instituições, tais como o Instituto Histórico e Geográfico de Mato Grosso (IHGMT), 5 em 1919, e

\footnotetext{
${ }^{5}$ A preocupação com a construção de uma memória oficial não tem como ato fundador a criação do IHGMT (LEOTTI, 2013). Em 1880, houve investimentos oficiais, patrocinados pelo governo provincial, para construir uma história oficial da qual a região ainda carecia. Entre as obras a serem publicadas estavam as pesquisas realizadas por Augusto João Manoel Leverger, conhecido como Barão de Melgaço, Vias de Comunicação de Mato Grosso e Apontamentos Cronológicos de Mato Grosso, e também as de Estevão de Mendonça, Quadro Chorográphico de Matto-Grosso. Leverger é considerado o maior historiador, geógrafo e estadista mato-grossense durante o Império. A deposição do presidente Antônio Paes de Barros, seguida da sua morte, e a posse do vice-presidente Pedro Leite de Osório, interromperam os trabalhos de publicação. Somente em 1947 as obras foram publicadas, cumprindo o que estabelecia a Lei no 561, de 27 de novembro de 1880. A obra de Estevão de Mendonça foi aprovada pelo Conselho Superior de Instrução Pública para ser utilizada como livro didático no ensino público primário. As revistas O Arquivo e Matto-Grosso, publicadas a partir de 1904, dedicavam seções sobre a história de Mato Grosso e já se aventava a possibilidade de ser fundado um Instituto Histórico.
}

Horizonte, Belo Horizonte, v. 16, n. 50, p. 780-811, maio/ago. 2018 - ISSN 2175-5841 
o Centro Matogrossense de Letras, ${ }^{6}$ em 1921, que aglutinaram o mesmo grupo de intelectuais, alguns anticlericais e adversários políticos de D. Aquino. Essas instituições receberam decisivo amparo do Estado, por meio de expressivas divisas seja para seu funcionamento, seja para a publicação dos seus trabalhos. Os que estavam dispostos a colaborar e a investir no ideário regionalista também receberam empregos públicos. D. Aquino tornou-se sócio-fundador dessas instituições, fornecendo as diretrizes a serem seguidas na redefinição da identidade regional. A política de cooptação e de burocratização da intelectualidade contribuiu para silenciar as diferenças ideológicas e os conflitos políticos, para homogeneizar os discursos regionalistas e para criar canais que facilitassem seu desempenho.

O IHGMT tinha como missão "coligir, methodizar, publicar ou archivar os documentos concernentes á história, geografia e arqueologia de Matto Grosso, bem como á etnografia dos seus indígenas e á biographia dos seus homens ilustres” (ESTATUTOS DO INSTITUTO HISTÓRICO DE MATTO-GROSSO, 1919, p. 8). Construir uma história oficial era, acima de tudo, preservar a memória e exaltar e glorificar o Mato Grosso e os feitos dos mato-grossenses.

Para divulgar as pesquisas e documentos, foi criada a Revista do Instituto Histórico e Geográfico de Mato Grosso. Para D. Aquino Corrêa (1919a, p. 1), havia entre os sertanistas e os mato-grossenses contemporâneos uma continuidade temporal e moral, pois partilhavam dos mesmos ideais: no passado, em 1719, com Paschoal Moreira Cabral, aflorava o ouro e, em 1919, a Revista do IHGMT. Nas duas primeiras edições, foram publicadas partes da antologia A Mato Grosso minha terra natal no seu bicentenario (CORRÊA, 1919e, p. 96). A coletânea versava sobre os fatos históricos, os heróis mato-grossenses e as belezas e riquezas da região, com imagens eivadas de sentimentalismos e de mitificações naturalistas da região.7 Cidades, fatos e personagens foram retratados nos poemas,

\footnotetext{
${ }^{6}$ Em 1932, passou a denominar-se Academia Matogrossense de Letras.

${ }^{7}$ Em 1926, foi lançada a obra Terra Natal, que reunia esses poemas. Na terceira edição, de 1940, foi acrescido um subtítulo, Terra Natal: versos a Mato-Grosso, o grande Estado do Oeste Brasileiro. A reedição foi comemorativa ao lançamento "da 'Marcha para Oeste' e a ereção do Monumento aos Heróis de Laguna e Dourados". D. Aquino dedicou a obra ao "Presidente da República Doutor Getúlio Vargas que proclamou a 'Marcha para Oeste'”' (CORRÊA, 1940b).
}

Horizonte, Belo Horizonte, v. 16, n. 50, p. 780-811, maio/ago. 2018 - ISSN 2175-5841 
construindo-se lugares de memória e, consequentemente, subjetividades e pertencimentos. ${ }^{8}$

Para Philogonio Corrêa (1919, p. 8), o papel do IHGMT era "imortalizar os feitos dos que se foram, imortalizar os heróes, escolher modelos para o futuro”. O objetivo era "tornar bem conhecidas a grandeza e a nossa raça [...] não deixando de apagar a memoria dos seus benemeritos", para que os mato-grossenses se orgulhassem do seu passado e seguissem os ensinamentos dos antepassados. Mato Grosso tinha inúmeras qualidades, tais como a grande extensão territorial, a variedade climática, a salubridade, as terras férteis, as riquezas minerais e as belezas naturais. Essas representações tinham como objetivo criar uma nova sociedade, um novo homem, um novo Mato Grosso e um novo país.

Em 1919, D. Aquino promoveu as comemorações do bicentenário da fundação de Cuiabá, que se tornaram um marco simbólico para solidificar a construção de novas identidades e centralizaram-se em torno das manifestações culturais para exaltar a terra e o homem mato-grossense. Também divulgariam as potencialidades econômicas da região, a estabilidade social e política já conquistadas e para a construção da imagem que identificava D. Aquino como o único capaz de promover a regeneração de Mato Grosso. Para os festejos, foram elaborados símbolos distintivos da identidade regional, como o brasão de armas (1918) e o hino mato-grossense (1918), que passaram a estar presentes nas repartições públicas, nas escolas e nas cerimônias oficiais, sendo também estampados nas publicações e nas correspondências oficiais. Os debates em torno dos limites territoriais entre Mato Grosso e Goiás foram retomados e, após várias negociações, foi confeccionada a carta geográfica de Mato Grosso, pois até aquele

\footnotetext{
${ }^{8}$ Pierre Nora (1997, p. 226) conceitua lugares de memórias como "toda a unidade significativa, de ordem material ou ideal, que a vontade dos homens ou o trabalho do tempo converteu em um elemento simbólico do patrimônio memorial de uma comunidade qualquer".
}

Horizonte, Belo Horizonte, v. 16, n. 50, p. 780-811, maio/ago. 2018 - ISSN 2175-5841 
momento o Estado carecia de delimitações territoriais. Outra iniciativa foi instituir o dia 8 de abril, data da fundação de Cuiabá, como feriado estadual. 9

Além da coesão das elites, as manifestações culturais e as políticas do bicentenário da fundação de Cuiabá foram importantes para a reafirmação da cidade enquanto capital. Como parte dos festejos, inúmeras intervenções urbanas foram realizadas, a fim de embelezar e civilizar a capital, reafirmando sua importância histórica e política e contrapondo-se, dessa forma, às reivindicações de transferência para Campo Grande, em virtude das aceleradas transformações econômicas, demográficas e sociais do sul de Mato Grosso.

O brasão de armas de Mato Grosso, instituído por D. Aquino, evocava as particularidades e as potencialidades de Mato Grosso, ou seja, "a nossa terra, a nossa gente, a nossa história, os nossos ideaes". Ao exaltar a "alma" e o "rosto", construía companheirismos e laços afetivos que ensejavam sentimentos de pertença. Sua simbologia reafirmava as heranças portuguesas por meio dos sertanistas paulistas (brasão da cidade de São Paulo) empunhando a bandeira católica (Cruz da Ordem de Cristo). A divisa latina Virtute plusquam Auro (confiemos mais na virtude que no ouro) valorizava o trabalho honesto e honroso em contraposição à falsa riqueza. O ouro, como riqueza aparente e inconstante, era encarado como um mal, enquanto o trabalho e as atividades produtivas, sobretudo as agrícolas, extrativas, pecuárias e industriais, assumiam a feição de riqueza verdadeira. As cores azul, verde, ouro e amarelo utilizadas na sua confecção eram cores nacionais e faziam alusão ao orgulho de pertencer à nacionalidade brasileira. Os mato-grossenses seriam herdeiros das suas tradições paulistas e da sua ação civilizatória, entre elas o catolicismo, o gosto pelo trabalho e o patriotismo. Como decorrência, geraram uma raça forte, superior e progressista (CORRÊA, 1919f, p. 162-164).

\footnotetext{
${ }^{9}$ Dom Aquino Corrêa (1926g) publicou a obra A Fronteira Mato Grosso - Goiás, memória sobre os limites entre os dois estados, em que apresentou os direitos de Mato Grosso sobre a região em litígio. A fronteira foi definida pela Constituição de 1937, no artigo 184.
}

Horizonte, Belo Horizonte, v. 16, n. 50, p. 780-811, maio/ago. 2018 - ISSN 2175-5841 
O Hino de Mato Grosso, cuja letra era o poema Canção Matogrossense, de autoria de D. Aquino, reforçava os valores já propostos no brasão: exaltava o homem, a natureza, o passado, a união entre os mato-grossenses e a inevitabilidade do progresso. Os sertanistas são elevados a heróis bandeirantes, por terem conquistado o "feroz Payaguá", por integrarem a região à nacionalidade brasileira e por trazerem a civilização, da qual os mato-grossenses eram herdeiros. O passado, representado como heroico, podia ser atestado na expansão das fronteiras a oeste e na defesa da soberania nacional durante a Guerra do Paraguai. A grandeza de Mato Grosso assentava-se na grande extensão territorial, na exuberância da natureza, nas potencialidades oferecidas pelo clima e pela natureza (CORRÊA, 1919d, p. 1920).

D. Aquino também teve um importante papel na criação do Centro Matogrossense de Letras, em 1921, e na definição dos caminhos que a instituição deveria trilhar. A missão era "lançar as bases da literatura regional" e promover e incentivar a cultura literária. Os temas a serem abordados deveriam ser os regionais, a fim de exaltar e divulgar o estado de Mato Grosso, sobretudo suas belezas naturais, riquezas inesgotáveis, fatos históricos, populações, heróis, tradições e costumes, expressões artísticas, variantes dialetais, religiosidades e o seu futuro, inevitavelmente glorioso. Ao mesmo tempo, a Literatura não deveria ser expressão de bairrismo, mas da inserção do regional na nacionalidade e na universalidade (CORRÊA, 1940a, p. 30-33).

Para cumprir seu papel, o CML deveria cultivar a "beleza da forma", ideal que seria conquistado por meio da filiação à escola literária parnasiana "da segunda metade do século findo", prestigiada por "Leconte e Herédia”, e que, segundo D. Aquino, dominava a "literatura nacional". Ao rejeitar quaisquer inovações, defendia que o parnasianismo seria uma reação salutar e fecunda contra a "infiltração" do romantismo (CORREAA, 1940a, p. 24). D. Aquino negava o romantismo, por apresentar tendências "descabeladas" e "revoltas" e por infiltrar o "pessimismo", a "tristeza sem esperança”. O parnasianismo, como reação, defendia a esperança. 
Segundo D. Aquino, o Centro deveria buscar a forma perfeita, supremo ideal do parnasianismo, e fazer a "literatura da esperança", "que eduque e eleve", que difunda "entusiasmos puros", "virtudes generosas", “crenças fortes", "patriotismos sinceros" e os "heroísmos que glorificam toda uma raça". Porém, seguindo as advertências de Euclides da Cunha, não deveria ser confundido com o parnasianismo decadente, que valorizava a "idiotice do culto fetichista da forma". A Literatura deveria "edificar a grandeza moral da Pátria, atraindo ao bem os corações mais broncos e refratários”, disseminando valores morais e cívicos e sentimentos de ufanismo e pertencimento à coletividade mato-grossense (CORRÊA, 1940a, p. 24-25, 36-38). A aspiração primordial era o esmero da linguagem, e o "cultivo do vernáculo" permitia criar versos "límpidos e cantantes, rimas claras e opulentas, estrofes impecáveis [...] imagens plásticas e esplendorosas", sem os quais não haveria a "beleza literária" (CORRÊA, 1940a, p. 24-27). A Literatura deveria preservar a brasilidade, a língua portuguesa e contrapor-se à ação dissolvente das ideias importadas e do imperialismo estrangeiro, que ameaçavam a cultura na medida em que se infiltravam.

O nacionalismo hiperbólico também deveria se expressar no cultivo da beleza e da "matéria", de modo a unir a "arte com a moral", ou seja, construir uma comunhão de "pensamentos e afetos", que "não só respeite a moral, mas a edifique, exalte e sublime". Nesse sentido, D. Aquino condenava as literaturas "passionais e corruptoras", como a "literatura das pornografias, que desvirginam a pureza dos sentimentos e afrouxam a integridades dos caracteres, desencadeando, a miude, sobre a família e a sociedade, os mais tremendos infortúnios" (CORRÊA, 1940a, p. 22, 35). A Revista do Centro Matogrossense de Letras, publicada a partir de 1922, tinha como fim divulgar a produção literária e redefinir a identidade coletiva.

Outro acontecimento importante para a redefinição identitária ocorreu em 1926, por ocasião das festividades do centenário da criação da diocese de Cuiabá. As comemorações tiveram feição religiosa e cívica e envolveram o governo federal, diferentes instituições e setores da sociedade civil. O evento foi realizado no Rio de 
Janeiro, a fim de dar maior visibilidade à ocasião e de divulgar Mato Grosso em nível nacional. Para D. Aquino, Mato Grosso era "para muitos, infelizmente, uma simples 'fantasia cartographica', ou seja, uma região pouco conhecida pelos brasileiros" (CORRÊA, 1926a, p. 4). Como decorrência, Aquino preferia "cantar as bellezas, do que expôr a pobreza do seu torrão natal”. Assim, as comemorações funcionavam "como acto de cultura cívica, como propaganda de um grande Estado quase inteiramente desconhecido, nas suas riquezas, nos seus homens, na sua mentalidade" (CORRÊA, 1926b, n. p.).

A construção de uma História e de uma Literatura oficiais, a mitificação do passado, por meio da eleição de episódios gloriosos repletos de personagens heroicos, a descoberta de vestígios, crenças e lugares comuns, a eleição de símbolos e emblemas regionais tinha como objetivo fortalecer o orgulho, os sentimentos de pertença, o patriotismo e a crença num futuro promissor. Construía-se o que Anderson (2008) denominou de comunidade imaginada. Consistia em forjar nos elementos díspares aspectos comuns que possibilitavam agregar e constituir um companheirismo horizontal e profundo e uma unidade regional pura, autêntica e coesa. Segundo D. Aquino Corrêa (1919c, p. 15), “somos um povo só, nascido e medrado dos mesmos céus e das mesmas terras, uma só família, cuja felicidade reside essencialmente da communhão dos ideaes, na concordia dos sentimentos e na solidariedade do trabalho de todos os seus membros”.

D. Aquino valorizava os fatos históricos, as heranças culturais e a pujança da terra. Seus discursos sobre o regionalismo assentavam-se no passado glorioso, nas heranças culturais, na pujança e potencialidade da terra, na extensão territorial de Mato Grosso e na valorização da brasilidade dos mato-grossenses. O objetivo era criar almas mato-grossenses, ou seja, sentimentos de amor e de orgulho pelo Mato Grosso e pelo Brasil grandioso, uno, soberano e progressista, pois ele acreditava na unidade e na indivisibilidade entre a Nação e o seu povo. Por outro lado, seus discursos regionalistas dissimulavam as diferenças étnicas e sociais constitutivas da sociedade e os conflitos intraelite, além de promoverem a individualização da 
região ao traçarem elementos distintivos do povo e do território (GALETTTI, 2000, p. 317-318). Segundo Zorzato (2000, p. 420), a construção identitária forjava uma “memória de consenso" que garantia a "primazia de mando" das elites cuiabanas sobre as novas demandas advindas das elites do sul do estado.

Em suma, D. Aquino, como membro da hierarquia eclesiástica, como intelectual e como governador, estava engajado nos projetos de pacificação de Mato Grosso, de redefinição identitária e de consolidação do catolicismo na sociedade. As representações criadas e legitimadas foram importantes para criar uma nova região, trazendo-a à existência, objetivando-a ao alterar e redefinir suas definições e identidades. Para Bourdieu (1989, p. 14), as representações podem "contribuir para produzir aquilo por ela descrito ou designado, quer dizer, a realidade objetiva”.

As ações e políticas de D. Aquino inserem-se num contexto mais amplo, ou seja, nas políticas da hierarquia eclesiástica brasileira e da Santa Sé de regenerar o Brasil, a política e o Estado e restaurar o domínio espiritual do catolicismo. Para conquistar esse objetivo, a hierarquia eclesiástica brasileira realizou alianças e colaborou com o Estado e com as elites e passou a se posicionar como força legitimadora do poder, disciplinadora da sociedade e defensora do caráter nacional, da catolicidade do povo brasileiro e do processo civilizatório. A nomeação de D. Aquino, como governador de Mato Grosso, foi autorizada pela Santa Sé e exemplifica esse projeto de cristianização social apoiada nas alianças da Igreja Católica com o Estado e as elites.

\section{D. Aquino e a construção da História mato-grossense}

Segundo D. Aquino Corrêa (1919b, p. 5), Mato Grosso era pouco estudado e conhecido até pelos mato-grossenses. As imagens de fronteira-sertão atribuídas à região e às suas populações eram vistas como caluniosas e seriam responsáveis por incalculáveis erros que produziam “consequencias desastrosas”. Tornar a região conhecida pelos brasileiros e estrangeiros possibilitaria desconstruir essas imagens 
estereotipadas, ou seja, quanto "mais conhecida, tanto mais rica, attrahente, encantadora”. Mato Grosso, pela sua grande extensão territorial (1.400.00o km²), teria infindáveis possibilidades econômicas, de inestimáveis riquezas e de clima salubre, ou seja, era uma terra privilegiada. A ferrovia Noroeste do Brasil teria revelado aos viajantes "um novo paraiso terreal no sul do Estado". Assim, Mato Grosso deveria ser mais bem estudado e divulgado por meio de publicações, reportagens e propagandas (CORREAA, 1919b, p. 5). Como governador, D. Aquino patrocinou a publicação de pesquisas e textos que divulgavam e construíam um imaginário edênico sobre Mato Grosso, associando-o à terra da promissão, onde corria leite e mel e onde todos os sonhos poderiam realizar-se. Esses discursos mobilizavam valores que faziam parte do imaginário religioso dos brasileiros, como a existência do paraíso terrestre, que garantiria um futuro promissor a todos.

A divisa latina do IHGMT Pro Pátria cognita atque immortali (pela pátria conhecida e imortal) trazia a lume as preocupações em preservar, divulgar e imortalizar a memória e tradições culturais regionais e a imortalidade da pátria. Para D. Aquino Corrêa (1919b, p. 6), existiam pátrias vivas e outras mortas, estas últimas quando seus "filhos" não conservavam nem celebravam as glórias do seu passado. Assim, para manter a pátria viva, era necessário manter as tradições herdadas, rememorar a História, manter o culto aos heróis e, dessa forma, construir modelos para o futuro. Seu objetivo era que o mesmo não ocorresse em Mato Grosso, daí a preocupação em rememorar continuamente, celebrar "as gloriosas tradições", “imortalizar a alma bandeirante e estoica do povo mattogrossense" e valorizar sua grandeza territorial, riquezas econômicas, variedades de clima, potencialidades e as heranças herdadas dos sertanistas (CORRÊEA, 1985c, p. 35).

Para o professor Philogonio Corrêa (1919, p. 7-8), secretário do IHGMT, a criação da instituição era um fato patriótico por trazer as lembranças dos "dous primeiros séculos da nossa vida politica, que há de perpetuar nas paginas da historia imparcial, para immorredouro exemplo" para as gerações futuras, 
tornando bem conhecidas "a nossa grandeza e a nossa raça”. Segundo D. Aquino Corrêa (1919b, p. 4), era um dever cívico de todos serem patriotas, amarem Mato Grosso e o Brasil e orgulharem-se deles. Por meio da religião, da História, das tradições comuns criavam-se laços de identificação coletivos e sensações emotivas de participação nos destinos do país.

Cabia à História e às Letras preparar "a glória imortal da nossa terra”, por meio da aliança “da religião e do patriotismo”, ou seja, de Deus e da Pátria. A poesia e a Literatura imortalizariam os fatos históricos, as memórias, os heróis e as tradições, tirando-os do silêncio, do abandono e do esquecimento ao perpetuá-los (CORRÊA, 1985f, p. 240). Em Mato Grosso,

surge-nos, de toda parte, um mundo de memórias históricas ou lendárias, esvaindo-se no olvido, à míngua de quem as perpetue no ouro do lavor literário. Escutai. O arraial da Forquinha, com a primeira igrejinha da nossa terra, a florida igrejinha de Nossa Senhora da Penha de França, há muito que desapareceu. A 'arvore dos bandeirantes' esfuma-se nas tradições populares. Os sítios históricos de S. Gonçalo Velho, com os restos da sua capela, jazem sepultados na capoeira bravia. A 'alavanca de ouro' suspira até hoje por um bardo. A vida apostólica de Frei Macerata refloresce por aí, nas mais encantadoras legendas, aguardando ainda a sagração definitiva das letras. (CORRÊA, 1985f, p. 239).

A História e a Literatura seriam as guardiãs das tradições, dos fatos, do culto dos heróis, garantindo sua imortalidade. Preservar a memória era um traço distintivo de civilidade de um povo:

Se morrem para sempre as Pátrias cujos filhos não souberam perpetuarlhe a vida nas brônzeas páginas indefectíveis da História, que, quando muito, conserva-lhe por um único epitáfio o nome, equivalente aliás, a um estigma perene da ignorância, esterilidade e barbárie. Não acontecerá o mesmo com Mato Grosso. Instala-se nesta hora, mercê de Deus, o seu Instituto Histórico, cujo esforço contínuo será reviver as gloriosas tradições e imortalizar a alma bandeirante e estóica do povo matogrossense. (CORRÊA, 1919a, p. 6).

Segundo D. Aquino, as maiores virtudes de um indivíduo seriam a religião e o patriotismo, sendo o heroísmo sua culminância, pois era hierarquicamente superior à genialidade, na medida em que o aspecto moral se sobrepunha ao 
intelectual. O heroísmo seria "a transcendência do homem para a divindade", pois era "a máxima ascensão da alma humana para Deus” e, por isso, seria imortalizado pela Igreja Católica, que o canonizava, e pela Pátria, que o glorificava (CORRÊA, 1985c, p. 27). Um herói da pátria também seria da Igreja Católica, pois "Deus [era] o inspirador e fautor de todos os heroísmos" (CORRÊA, 1985c, p. 28-29). Pátria e Deus seriam inseparáveis, pois a pátria era a "maior revelação da divindade" e separá-los seria materializar, irracionalizar e dessacralizar, excluindo sua soberania, majestade, grandeza e perenidade (CORRÊA, 1985e, p. 101).

Ter uma pátria era uma das condições básicas para a felicidade dos indivíduos, pois os homens nasciam para "viver em sociedade, como [cidadãos] de uma Pátria”, e trabalhar pelo seu engrandecimento, acima dos interesses individuais, contribuiria para a felicidade de todos (CORRÊA, 1919b, p. 4). Essa política do desprendimento levava obrigatoriamente a priorizar o país e a contar com a colaboração de todos os cidadãos, numa comunhão de interesses de todas as classes sociais com os governantes, a fim de manter a integridade regional e nacional e uma atitude vigilante contra tudo que pudesse ameaçá-la. D. Aquino explicava, à luz de Aristóteles e da doutrina católica, o dever de obedecer, de trabalhar para seu desenvolvimento e de sacrificar-se para defender o estado de Mato Grosso e o Brasil. Ou seja, o Evangelho não excluía o patriotismo, mas impunha, de forma clara e imperiosa, o "dever de amarmos, servirmos e defendermos ate o sangue, a nossa Pátria” (CORRÊA, 1919b, p. 4).

O patriotismo gerava outros sentimentos, como o civismo, ou seja, os deveres para com a pátria e a consciência de que cada concidadão se considerasse uma parcela do patrimônio nacional, a se autovalorizar física, moral e intelectualmente, a respeitar as autoridades e as leis e a trabalhar, lutar ou morrer para defender a pátria e orar por ela (CORRÊA, 1985a, p. 35-36). Os indivíduos deveriam se aperfeiçoar, sobrepor os interesses coletivos sobre os pessoais, trabalhar pela prosperidade de Mato Grosso e do país e defender sua soberania, com a própria vida se fosse necessário. Era uma necessidade moral orgulhar-se de 
valores como o dever e a honra, entre outros, bem como aprimorá-los e cultivá-los (CORRÊEA, 1985a, p. 35-36). A população, unida em torno dos ideais de fé e patriotismo, deveria apoiar os governantes e solidarizar-se com eles, a fim de assegurar a grandeza de Mato Grosso e do país (CORRÊA, 1985g, p. 187).

D. Aquino se apropriou da interpretação de Francisco José de Oliveira Vianna, sobretudo da obra Evolução do povo brasileiro, publicada em 1922, em que afirmava que o país não constituía uma unidade e o percebia a partir das perspectivas regionais, valorizando, dessa forma, a heterogeneidade da formação brasileira. As diferenças regionais teriam sido criadas a partir de fatores raciais, históricos, geográficos, ecológicos, sociais e culturais diversos, que contribuíam para o desenvolvimento de distintos tipos sociais.

D. Aquino e os membros do IHGMT e do CML, para desmitificarem as imagens de que Mato Grosso era povoado por populações bárbaras, doentes, sem iniciativa, incapazes e incapacitadas à civilização, repensaram a constituição do povo mato-grossense. Para refutar essas imagens, adotaram como fundamento histórico o sertanismo, ressaltando sua capacidade de se adaptar ao meio, de conviver e de assimilar as raças inferiores. Ao harmonizarem os conflitos interétnicos, dissiparam a existência de fronteiras biológicas. O mato-grossense seria o resultado da fusão de variados tipos raciais, tais como portugueses, paulistas, indígenas e escravizados. Também foi destacada a participação dos goianos, mineiros e gaúchos (CORRÊA, 1926a, p. 39). A miscigenação de raças díspares foi vantajosa, pois gerou uma população superior em nível racial e cultural a partir da crença numa hierarquia étnica, segundo a qual o branco, por ser mais evoluído, predominaria sobre as demais raças, produzindo uma sociedade branca e superior e sem preconceito de cor (CORRÊA, 1919b, p. 6). Como legado da "seleção natural" e da predominância da raça superior sobre a "mescla de grosseira superstição do africano e a theogonia primitiva do indígena”, seria gerada uma raça “forte”, "pujante” e “extraordinária” (CORRÊEA, 1926c, p. 39-40). Ao construir uma unidade étnico-cultural, forjaram uma sociedade harmoniosa e integrada numa só 
alma e direção, assentada no trabalho, na paz, na ordem e tolerância, no respeito às leis e hierarquias e na equidade.

Para D. Aquino, os mato-grossenses não tinham motivos para se envergonhar dos seus antepassados e da sua cor. Deveriam, ao contrário, ufanar-se por descender de um povo nobre, católico e superior em nível étnico e cultural, do qual teriam herdado valores tais como a impavidez, a coragem, o patriotismo, entre outras qualidades, além de ideais nobres, como o nativismo, o catolicismo, o abolicionismo e o republicanismo.

Os sertanistas paulistas, como pais fundadores, foram mitificados pela cor branca, pela descendência europeia, por imprimirem traços psicológicos (que formaram o tronco moral da sociedade), pelo progresso, pelo cristianismo que trouxeram, pela sua valentia na ampliação e na defesa das fronteiras nacionais e por sua ação civilizadora (CORRÊA, 1926a, p. 39). D. Aquino parafraseou SaintHilaire, que qualificou os paulistas como uma "raça de gigantes", e Taunay, que os definiu como “os constructores épicos do Brasil central e meridional” (CORREA, 1926c, p. 40). Os paulistas, pela sua capacidade de movimentação, organização e cooperação, seriam "intrépidos devassadores do sertão", ao empreenderem a conquista territorial, ao alargarem a fronteira a Oeste e terem-na defendido, consolidando a posse e definindo os limites nacionais. Nessa interpretação, a ampliação da fronteira e sua defesa seriam uma obra exclusivamente brasileira, sobretudo mato-grossense, que, pela sua bravura, antepôs-se às convenções internacionais. ${ }^{10}$ Como decorrência, Mato Grosso seria o estado mais brasileiro do Brasil, embora fosse uma das últimas regiões a se integrar ao seio da nacionalidade (CORRÊA, 1926c, p. 40-41).

D. Aquino postulava imagens distintivas e inerentes ao ser mato-grossense, que seria religioso, culto, inteligente, nobre, sóbrio, corajoso, empreendedor,

\footnotetext{
${ }^{10} \mathrm{~A}$ brasilidade dos mato-grossenses poderia ser atestada na ampliação das fronteiras no período colonial e imperial e na sua defesa, apesar da extensão de três mil quilômetros, da rarefação demográfica e do pequeno apoio governamental.

Poderia ser observada ainda na incorporação do indígena à civilização e por priorizar os interesses nacionais sobre os regionais ao ceder parte do território de Mato Grosso à Bolívia (Tratado de Petrópolis, de 1903).
}

Horizonte, Belo Horizonte, v. 16, n. 50, p. 780-811, maio/ago. 2018 - ISSN 2175-5841 
civilizado e patriota (CORRÊA, 1926c, p. 38-39). Ao valorizar a contribuição dos paulistas à cultura mato-grossense, ressaltou seu papel apostólico, sobretudo em difundir o catolicismo, que se constituiu num dos fundamentos da sociedade. Assim, Mato Grosso teria nascido sob o signo da cruz, por herança cultural paulista e, posteriormente, mineira e goiana. $\mathrm{O}$ amor pátrio, o civismo e o espírito apostólico moviam os bandeirantes a ampliar as possessões portuguesas, a lançar os fundamentos da sociedade cristã e a preparar "os alicerces do seu venerando sólio episcopal” (A SANTA SÉ e o Estado de Mato Grosso no bicentenário da fundação de Cuiabá, s.d., p. 10-11). Esse aspecto pode ser observado no fato de os arcebispos de Cuiabá serem enterrados na catedral ao lado dos restos mortais de Pascoal Moreira Cabral e Miguel Sutil de Oliveira, que foram considerados os primeiros bandeirantes a chegar à região, construindo-se uma relação de continuidade entre eles.

Os bandeirantes e os padres missionários, como precursores da Igreja, seriam "continuadores de Anchieta”, “a vanguarda da Egreja”, "heróes da epopéa civilizadora", “apóstolos" ou "martyres anonymos da civilização". Esses agentes civilizadores, ao pontilharem suas conquistas com a cruz católica, eram heróis, embora sem anfiteatros ou poemas (CORRÊAA, 1926a, p. 13, 24-25). O patriotismo e a religiosidade, expressos pelos heróis do panteão cívico mato-grossense, eram reivindicados à causa da Igreja na recristianização social e na retomada do seu papel central na sociedade.

D. Aquino elegeu um panteão cívico e estimulou o culto, pois os heróis serviriam de modelos e arquétipos para os valores e as aspirações coletivas, tais como disseminar virtudes militares, cívicas, patrióticas e cristãs e demonstrar a importância dos princípios da ordem, hierarquia e autoridade. Os heróis deveriam ser homenageados e celebrados em conferências, discursos, sermões, cerimônias e poesias, a fim de inspirar a coletividade. Ao propor uma estrutura afetiva, que criasse uma unidade e um todo harmônico, Aquino valorizou os indivíduos que 
professavam o catolicismo, pois associavam suas trajetórias de vida à fé com o patriotismo. Sua sacralização conferia maior força às suas imagens.

$\mathrm{Na}$ seleção dos heróis, não importava o local de nascimento desses indivíduos, mas as suas qualidades atávicas. Como decorrência, todos foram representados como sendo mato-grossenses, a fim de criar um passado glorioso e heroico. Entre os heróis eleitos estavam os sertanistas paulistas, os participantes da Guerra do Paraguai e outros indivíduos que se destacaram pelos seus feitos. Suas qualidades e trajetórias foram enaltecidas, tais como sua capacidade de liderança e de iniciativa e seus valores políticos, ideológicos, religiosos e morais, sobretudo o civismo. Para D. Aquino Corrêa (1919b, p. 10), um dos aspectos a serem celebrados era a história militar de Mato Grosso, sobretudo as “conquistas pacíficas” que comprovavam a intervenção divina em favor do Brasil. Associavam-se, dessa forma, a catolicidade e a brasilidade, pois o país teria sido consagrado desde seu nascimento à Igreja Católica e a Deus.

Segundo D. Aquino Corrêa (1985b, p. 156), a eficácia do catolicismo na história brasileira podia ser atestada em duas "campanhas: a holandesa e a paraguaia”. A vitória sobre o inimigo foi atribuída ao rito instituído pela Igreja Católica de benzer as bandeiras e as espadas, sagrando-as à vitória, “dentro da lei e da justiça” (CORRÊA, 1985d, p. 60). A civilização brasileira estaria assentada nas alianças entre a "Espada e a Cruz", que, ao unirem o poder da força e do espírito, teriam garantida a vitória sobre os inimigos (CORRÊA, 1985h, p. 228). A Guerra do Paraguai foi considerada a mais digna de admiração, e o episódio da Retirada da Laguna, o mais notável e heroico da história brasileira. Outros episódios gloriosos foram a defesa e retirada do Forte de Coimbra, a tomada e retomada da cidade de Corumbá, a retirada do tenente Melo e os “martírios” de Antonio João Ribeiro, Carlos de Moraes Camisão e José Francisco Lopes, representados como sentinelas avançados da integridade nacional (CORRÊEA, 1985i, p. 32).

Horizonte, Belo Horizonte, v. 16, n. 50, p. 780-811, maio/ago. 2018 - ISSN 2175-5841 


\section{A recepção da produção intelectual de D. Aquino}

D. Aquino, entre as décadas de 1920 e 1940, tornou-se uma figura de proeminência em nível nacional ao conquistar grande influência social e política como poeta e escritor, sendo considerado o maior poeta mato-grossense. Segundo Favero (1996, p. 101, 116), ele teria composto mais de quatrocentas poesias, reunidas em três obras, Odes (1917), Terra Natal (1919) e Nova e Vetera (1947), e redigido 85 discursos, 25 pastorais e duas pastorais coletivas da Província Eclesiástica de Cuiabá. Sua capacidade de comunicação e de utilizar, com brilhantismo, os recursos oferecidos pela oratória (infundindo-lhes emoção) e seu carisma pessoal fizeram com que seus sermões fossem admirados e que ele fosse reconhecido em nível nacional como orador. D. Aquino discursou em estádios, festas, praças, catedrais, estádios, rádios, congressos eucarísticos, reuniões e formaturas, missas campais, prefeituras, romarias e na inauguração de um hipódromo. Também representou o governo brasileiro em diferentes ocasiões, inclusive na Conferência Internacional de Educação em Genebra. Em 1926, foi eleito para a Academia Brasileira de Letras (ABL) e para o Instituto Histórico e Geográfico Brasileiro (IHGB).

A produção intelectual de D. Aquino é vasta e pauta-se por um nacionalismo e moralismos extremados, o que o fez ter muitos adeptos. São inúmeros poemas, discursos, cartas pastorais e crônicas, que o tornaram uma autoridade e referência obrigatória para os pesquisadores. Sua atuação política e cultural o tornou um arauto de Mato Grosso, ao divulgar a memória regional, as qualidades das suas terras e gentes, redefinindo sua identidade e suas representações.

Affonso Celso, na posse de D. Aquino no IHGB, destacou o passado glorioso de Mato Grosso, por ser "fulgente de feitos heroicos dignos de consagração epica, quer no período dos bandeirantes, quer em guerras coloniaes, quer na campanha do Paraguay, região brasileira que mais soffreu; pelos filhos illustes que tem dado à Patria”. D. Aquino, como sócio honorário, teria a missão de "prestar culto aos [...] 
compatrícios ilustres" e "empenhar-se em cultivar, desenvolver, valorizar tamanha preciosidade da União” (CELSO, 1926b, n.p.). Cesario Prado (1926), por sua vez, ressaltou as qualidades estéticas e patrióticas dos seus poemas, desde que começou a escrever, quando estudava em Roma, igualando-o a Olavo Bilac:

E, também, como fortificado pela visão da pátria distante, o patriotismo de D. Aquino compunha em Roma esses carmes, que as anthologias nacionais têm recolhido em suas paginas para a educação cívica da mocidade: 'Pindorama', 'Bandeira do Brasil, e outros cantos de D. Aquino, a competirem com os de Bilac na belleza da harmonia e na inspiração patriotica, são por isso sobejamente conhecidos em todos os Estados. (PRADO, 1926, não paginado).

O jornal O Imparcial, ao divulgar a publicação de Terra Natal, representava D. Aquino como um "espírito culto de prelado e escritor" por "cantar hymnos de louvor a Matto Grosso e aos seus vultos historicos de mais destaque”, bem como a São Paulo, "terra das bandeiras e da liberdade", por ter servido de berço. Como sacerdote e poeta, tinha um "estylo bucolico que prende e encanta" ao tratar de “vários temas com elevação de sentimento, com graça e delicadeza”. Os seus versos "encantam pela ternura em que são burilados, e deslisam serenos com a sonoridade de um regato a cabriolar por entre seixos". Assim, poderia, "sem favor algum, figurar entre as obras mais poeticas e mais bellas e de sentimento que hão escripto nestes ultimos tempos”. Como estudioso, cultivava a língua “"na licção assidua dos modelos', a belleza da forma e da matéria na literatura, condemnando, acremente, o pessimismo" entre a juventude (LIVROS NOVOS..., 30 set. 1926, p. 4).

Benjamin Franklin Ramiz Galvão destacou as qualidades estéticas das coletâneas Terra Natal e Odes, que se filiavam à “eschola de Roma”, ou seja, ao profeta Jeremias, aos provérbios de Job e aos grandes nomes do Renascimento, tais como Rafael Sanzio, Giovanni da Fiesole (mais conhecido como Fra Angelico) e Giovanni Pierluigi da Palestrina. Suas obras seriam hinos de defesa da fé, do patriotismo e do nacionalismo, valores considerados superiores, pois despertavam e aprimoravam os sentimentos de dever para com o país e com Deus:

Horizonte, Belo Horizonte, v. 16, n. 50, p. 780-811, maio/ago. 2018 - ISSN 2175-5841 
Um hynno ardoroso, cantado como eminente Cuiabano aos heróes do seu berço, ás cidades e aos grandes rios do Estado, - um 'que riça o immenso dorso em mil cachoeiras, como um dragão a urrar nas ondas bravas', outro 'que não rola majestosamente sobre diamantes, na Itaipava hirsuta'. Outra obra lavrada com primor por V. Ex. Revma. tem por titulo Odes, onde refulge o talento de um poeta christão; ha alli 'os transportes deliciosos de uma alma de noviço, de sacerdote e de bispo, para quem Deus é o ideal dos ideaes, a Poesia infinita, pela qual tudo é bello, e sem o qual tudo é nada.'

O Preludio, que antecede a este novo collar de perolas, offerecido pelo autor aos seus contemporaneos, retrata-lhe egualmente o alto espirito religioso e são, inspirado nas fontes purissimas do Christianismo, nas 'velhas paginas de Job, no perenne extase lyrico dos Cantares, no spatheticos threnos de Jeremias, no estylo grandioso dos Prophetas, nas encantadores parabolas do Divino Mestre'. Sempre palavras de V. Ex. e palavras de ouro.

[...] V. Ex. é de certo um grande servidor de Deus e da Patria. Em nome de Deus a Posteridade o bemdirá; em nome da Patria, o Instituto Historico e Geographico Brasileiro, que é templo das nossas tradições seculares, e onde também o culto da Patria e da Justiça impera soberano - o Instituto o saudará, como hoje o saúda, com palmas calorosas.

Salve! Insigne batalhador da Fé! Salve! cultor insigne da Poesia, que eleva os corações ao infinito, e da Historia, que é a luz da Verdade, que é a grande Mestra da Vida! (Prolongadas palmas). (GALVÃO, 1926, não paginado, grifos do autor).

Max Fleiuss, ao comentar o discurso de posse, destacou que, quando D. Aquino subiu na tribuna, provocou "em toda a sala, o fremido, que precede ás grandes ovações: primeiro movimento instinctivo de admiração", pois a figura do orador se impunha, seu nome era garantia de "sucesso" e a "expectativa foi excedida”. Também foram ressaltadas as qualidades estéticas e o patriotismo dos seus poemas, ao consagrarem os heróis, a História e as belezas naturais de Mato Grosso. O bispo poeta teria o dom de encantar e envolver os leitores, por ter uma “mentalidade superior”, no sentido de que somente um corpo são pode produzir ou sustentar um coração patriótico e nacionalista e dedicado à cultura superior: "Mens sana in corde sano!”.

A figura do orador se impunha [...] a oração a ultrapassou em belleza, idéas, ideais, rythmo da prosa vernacula, no enunciado claro, preciso, vibrante como um hyno cantando a terra e os bandeirantes, as victorias e as lutas, imprimindo a nota de piedade e de gloria, pelos que cahiram, pelos que vingaram.

Não conhecemos no clero da nossa Patria, quem exceda a D. Aquino na arte de dizer não só com palavras, mas tambem com a alma, de dizer transbordando os frutos do espirito e os effluvios do coração. [...]

Horizonte, Belo Horizonte, v. 16, n. 50, p. 780-811, maio/ago. 2018 - ISSN 2175-5841 
Abra-se, por exemplo, a 'Terra Natal' e leiam-se seguidamente os versos, desde 'Virtute plusquam auro' ao 'Boi cuiabano', e, de pagina em pagina, a admiração augmenta, acompanhando o poeta no exalçar a terra e os seus homens.

Dir-se-ia um breviário de bellezas, que encantam e consolam, que arrebatam ou pungem, que descrevem uma scena ou consagram um heróe. (RASCUNHOS, 1926, p. 2).

Para Affonso Celso, o arcebispo pertencia à "família espiritual” dos grandes doutores e "homens de letras", como Jacques-Bénigne Bosseut, François Fénelon, S. Francisco de Salles e Cardeal Désiré-Félicien-François-Josep Mercier. Em sua poética, "[dominava] o pensamento religioso, a inspiração da cruz" e o patriotismo, pois o abandono desses valores conduziria a sociedade ao caos, à anomia, à barbárie e à instabilidade social. Terra Natal teria sido ordenado na seguinte lógica: seu primeiro texto era a letra do Hino Mato-grossense e os demais explicariam seu desenvolvimento:

Celebra o brazão do Estado, a sua geognose, os seus aborígenes, os bandeirantes, as monções, as lendas locaes, os heroes do descobrimento e povoação: Moreira Cabral, Rodrigo Cesar de Menezes, Rolim de Moura, Leverger, os episódios epicos de Antonio João, Retirada da Laguna, Gruta de Coimbra, as regiões mais caracteristicas da immensa unidade da Federação, o que tudo merece bem traçado soneto, de metrica, linguagem e naviosidade irreprehensiveis.

Noutras composições mais extensas, como - Rio das Mortes - narra, em traços impressionantes, as lutas dos emboabas com os selvagens, as terríveis e obscuras tragedias, que assignalaram a conquista do sertão.

Em tudo domina o pensamento religioso, a inspiração da cruz [...]. (PRADO, 1926, não paginado, grifo do autor).

Affonso Celso (1926a, n.p.) qualificava D. Aquino como um erudito, "rico em virtudes, estudioso da belleza, solicito do decoro das cousas divinas e pacificador, já na sua diocese, já no seu Estado, do qual foi benemerito presidente". Seus textos eram celebrados pela "beleza da forma literaria, do estudo do vernaculo", sendo considerado herdeiro de Rui Barbosa, para quem a Literatura deveria

[professar] cavalleiramente a bella divisa de um dos nossos homens de letras: Aedificabo! literatura que saiba edificar a grandeza moral da Patria, attrahindo ao bem os corações ainda os mais broncos e refractarios, como a dourada lyra do Amphião, sob o encanto magico das suas melodias, arrastava as pedras da Beocia, para aa construcção dos legendarios muros de Thebas". (CELSO, 1926a, não paginado). 
Por ocasião das comemorações do centenário da criação da diocese de Cuiabá, em 1926, foi celebrado como "batalhador da Fé", "cultor insigne da Poesia", da "Pátria e da Justiça" e um indivíduo dotado de qualidades estéticas notáveis. Seu discurso Heroes Obscuros da Egreja de Mato Grosso seria uma "peça notavel cheia de vibração e de brilho, onde se revela admiravelmente um espirito devotado ás pesquizas historicas”, divulgando Mato Grosso, seus opulentos recursos, suas infindáveis possibilidades e seus feitos na "guerra e na paz" (O CENTENARIO DO BISPADO DE CUYABÁ, 27 jul. 1926, p. 10).

Em sua posse na Academia Brasileira de Letras, em 30 de novembro de 1927, foi homenageado como um "poeta de fina sensibilidade, prosador de estylo fluente e elegante, tribuno de largos recursos" e como um patriota acendrado. (NA ACADEMIA BRASILEIRA..., 30 nov. 1927, p. 5). D. Aquino preferia a literatura nacional às "exóticas leituras", que "[eivavam] a limpidez da nossa linguagem" e deturpavam o cultivo do vernáculo (CORRÊA, 1985f, 238).

\section{Considerações finais}

As políticas e intervenções de D. Aquino na esfera cultural foram importantes para a redefinição identitária de Mato Grosso. A Igreja Católica e o Estado, por meio do bispo-governador, assumiram os papéis de tutores, salvadores e orientadores de um projeto político, econômico e cultural, a fim de salvar o Estado da crise política. D. Aquino, na busca de um futuro, acelerou o processo de reconstrução da identidade regional, inserindo-a como substrato da identidade nacional. O clima, a natureza, a mistura de raças, vistos como negativos por se assentarem em valores europeizados, foram alterados e novas perspectivas foram apresentadas.

Ao definir o povo e a sociedade, criou laços afetivos, ao costurar as diferenças existentes numa unidade. O objetivo era superar a crise política, afirmar a importância de Cuiabá como capital de Mato Grosso, manter as elites nortistas no 
controle do governo estadual e a construir um projeto coletivo de desenvolvimento econômico, político e social. A unidade cívica e religiosa dos mato-grossenses era vista como expressão do bem e do bom, pois Mato Grosso era o espaço da nova civilização e do futuro. O otimismo caracterizava a redefinição identitárias e as promessas eram de um futuro glorioso, civilizado, moderno e próspero.

A História, a Literatura e a Geografia foram importantes nesse processo, sobretudo para difundir valores éticos e morais, os deveres dos cidadãos e as suas contribuições para o desenvolvimento e para defesa de Mato Grosso e do país. D. Aquino, como membro da hierarquia eclesiástica, valorizava e defendia as tradições católicas e a importância da Igreja Católica no controle social e na difusão de valores. São temáticas recorrentes em sua poética, sermões e discursos o nacionalismo; o patriotismo; o autoritarismo, a mitificação da História; o culto aos grandes homens e heróis (que definiram as fronteiras nacionais ou morreram pelo país); o retorno às tradições herdadas (sobretudo o catolicismo); o saudosismo do passado; a valorização dos aspectos religiosos da cultura regional; as associações entre o Estado, a Pátria, a Nação e o povo; a opulência e a rudeza da natureza matogrossense; as potencialidades e riquezas econômicas de Mato Grosso, que garantiriam um futuro próspero e civilizado; a idealização romântica das populações indígenas; e o orgulho de pertencer às terras mato-grossenses.

As construções da unidade, da comunidade, das identidades regional e nacional, do patriotismo, do nacionalismo e do ufanismo estão nas bases dos regimes autoritários. Seu conservadorismo se manifestou na defesa de um Estado que fosse centralizado, autoritário, interventor, nacionalista e que combatesse os inimigos da Igreja Católica e da sociedade. Para D. Aquino, a posse de Getúlio Vargas marcou o fim de um período de trevas e foi o resultado da intervenção da providência divina para extirpar o "Estado leigo e ateu" e reintroduzir Deus na sociedade. A "revolução triunfante" de Vargas representava o fim de três "males capitais": o "enfraquecimento do princípio de autoridade, a carência de lei constitucional e a infiltração comunista” (CORRÊA, 1985b, p. 129-130, 150, 145). 
$\mathrm{Na}$ colaboração entre os poderes temporal e espiritual, valorizava o papel disciplinar e civilizador da Igreja Católica ao difundir o civismo e valores como a obediência às autoridades e às leis, ordem, hierarquia e disciplina, pois sem esses fundamentos e sem a religião católica seriam perpetuadas as crises políticas, sociais e morais. Assim, defendia a cristianização social apoiada nas alianças com o Estado e com as elites, buscando consolidar uma posição de destaque para a Igreja Católica e obter, dessa forma, privilégios e posições vantajosas.

Por fim, os discursos de D. Aquino eram revestidos de autoridade, pois falava como religioso, como arcebispo, como intelectual e como membro do IHGMT, do IHGB, do Centro Matogrossense de Letras e da Academia Brasileira de Letras. Em Mato Grosso, era reconhecido pela sua atuação política e religiosa, por ser um arauto da identidade regional e por divulgar e construir representações positivas de Mato Grosso em nível nacional e internacional. A partir da década de 1950, devido à sua vinculação com Getúlio Vargas e à piora do seu estado de saúde, foi colocado no ostracismo pela hierarquia eclesiástica. Porém, continua a ser respeitado e a ter seguidores até na contemporaneidade.

\section{REFERÊNCIAS}

A SANTA Sé e o Estado de Mato Grosso no Bicentenário da fundação de Cuiabá:

MDCCXIX - MCMXIX. S. n. t.

ANDERSON, Benedict. Comunidades imaginadas: reflexões sobre a origem e difusão do nacionalismo. São Paulo: Companhia das Letras, 2008.

AYALA, S. Cardoso; SIMON, Feliciano (Org.). Álbum gráfico do Estado de Mato

Grosso. Hamburgo; Corumbá: [s. n.], 1914.

BI-CENTENÁRIO DE CUIABÁ - Festas Comemorativas. Revista do Instituto

Histórico e Geográfico de Mato Grosso, Cuiabá, Anno I, Tomo II, p. 165-172, 1919.

BOURDIEU, Pierre. O poder simbólico. Lisboa: Difel, 1989.

CANTO-SPERBER, Monique (Org.). Dicionário de ética e filosofia moral. São Leopoldo: UNISINOS, 2003. v. 2. 
CASTRILlON-MENDES, Olga Maria. D. Aquino Corrêa e D. Pedro Casaldáliga: entre o universo telúrico, a fé e o poder. Revista Ecos, Cáceres, v. 16, p. 121-131, 2014.

CELSO, Affonso. D. Aquino Corrêa. In: CORREA, D. Francisco de Aquino. Centenário do bispado de Cuiabá no Rio de Janeiro. Rio de Janeiro: [s. n.], 1926a.

CELSO, Affonso. O centenário da Diocese cuiabana. In: CORREA, D. Francisco de Aquino. Centenário do bispado de Cuiabá no Rio de Janeiro. Rio de Janeiro: [s. n.], 1926b.

CHARTIER, Roger. A história cultural: entre práticas e representações. Lisboa: Difel; Rio de Janeiro: Bertrand, 1988.

CORRÊA, D. Francisco de Aquino. A bandeira da pátria. Na prefeitura do Distrito Federal, ao ser condecorado o aluno salesiano, que saldara o Pavilhão Nacional, no naufrágio da Barca Sétima. Rio de Janeiro, 19 de novembro de 1915. In: SILVA, Corsíndio Monteiro da (Org.). Dom Francisco de Aquino Corrêa - Discursos. Brasília: Imprensa Nacional, 1985d. v. 1. p. 57-61.

CORREAA, D. Francisco de Aquino. A fronteira Mato Grosso-Goiaz: memória sobre os limites entre os dois estados. Cuiabá: Typ. Oficial, 1919g.

CORRÊA, D. Francisco de Aquino. À maneira de prefácio: o belo nas Letras. Discurso oficial proferido pelo autor, na instalação do Centro, hoje Academia Mato-grossense de Letras, a 7 de setembro de 1921. In: CORRÊA, D. Francisco de Aquino. Terra Natal: versos. Rio de Janeiro: Imprensa Nacional, 1940a. p. 17-39.

CORREAA, D. Francisco de Aquino. A Revista. Revista do Instituto Histórico e Geográfico de Mato Grosso, Cuiabá, Anno I, Tomo I, p. 1-3, 1919 a.

CORREAA, D. Francisco de Aquino. Aos Heróis de Laguna e Dourados. Revista do Instituto Histórico e Geográfico de Mato Grosso, Cuiabá, Anos XXIII e XXIV, Tomos XLV-XLVIII , p. 3-10, 1941-1942.

CORREAA, D. Francisco de Aquino. Aos heróis de Laguna e Dourados. Ao serem inumados os restos mortais da Praia Vermelha. Rio de Janeiro, 15 de novembro de 1941. In: SILVA, Corsíndio Monteiro da (Org.). Dom Francisco de Aquino Corrêa - Discursos. Brasília: Imprensa Nacional, 1985i. v. 3. p. 29-36.

CORREAA, D. Francisco de Aquino. Bicentenário. Revista do Instituto Histórico e Geográfico de Mato Grosso, Cuiabá, Anno I, Tomo I, p. 14-15, 1919 c.

CORREAA, D. Francisco de Aquino. Centenário do bispado de Cuiabá no Rio de Janeiro. Rio de Janeiro: [s. n.], 1926b.

CORRÊA, D. Francisco de Aquino. Centenário do bispado de Cuiabá: a sessão de 26 de julho de 1826 do Instituto Histórico e Geographico Brasileiro. Rio de Janeiro: Imprensa Nacional, 1926a. 
CORREAA, D. Francisco de Aquino. Deus e pátria. In: SILVA, Corsíndio Monteiro da (Org.). Dom Francisco de Aquino Corrêa - Cartas pastorais. Brasília: Imprensa Nacional, 1985b. v.1. p. 128-156.

CORRÊA, D. Francisco de Aquino. Discurso: Pro Pátria Cógnita Atque Immortali. Allucção proferida na instalação do Instituto Histórico de Matto-Grosso em 8 de Abril de 1919. Revista do Instituto Histórico e Geográfico de Mato Grosso, Cuiabá, Anno I, Tomo II, p. 3-6, 1919b.

CORREAA, D. Francisco de Aquino. Mensagem dirigida pelo presidente D. Francisco de Aquino Corrêa à Assembleia Legislativa em 13.05.1918. In: CORRÊA, Dom Francisco de Aquino. Relatórios de presidente de províncias, 1918. Fonte: Arquivo Público de Estado de Mato Grosso (APMT), Mato Grosso.

CORRÊA, D. Francisco de Aquino. Mensagem Presidencial que cria o Brazão d'Armas do Estado de Matto-Grosso. Revista do Instituto Histórico e Geográfico de Mato Grosso, Cuiabá, Anno I, Tomo II, p. 162-164, 1919 .

CORREAA, D. Francisco de Aquino. No Ipiranga. Por ocasião da romaria cívica dos alunos Salesianos, no Centenário da Independência. São Paulo, 12 de outubro de 1922. In: SILVA, Corsíndio Monteiro da (Org.). Dom Francisco de Aquino Corrêa: discursos. Brasília: Imprensa Nacional, 1985e. v. 1. p. 99-105.

CORREAA, D. Francisco de Aquino. O patriotismo cristão. In: SILVA, Corsíndio Monteiro da (Org.). Dom Francisco de Aquino Corrêa - Cartas pastorais. Brasília: Imprensa Nacional, 1985a. v.1. p. 30-37.

CORRÊA, D. Francisco de Aquino. Oração pela pátria. Em missa campal, no "Dia da Pátria”. Cuiabá, 7 de setembro de 1937. In: SILVA, Corsíndio Monteiro da (Org.). Dom Francisco de Aquino Corrêa - Discursos. Brasília: Imprensa Nacional, 1985g. v. 2. p. 187-189.

CORREAA, D. Francisco de Aquino. Os meus ideais literários. In: SILVA, Corsíndio Monteiro da (Org.). Dom Francisco de Aquino Corrêa - Discursos. Brasília: Imprensa Nacional, 1985f. v. 1. p. 233-246.

CORRÊA, D. Francisco de Aquino. Religião e tradicionalismo (Conferência lida na sessão solenne promovida, a 15 de Julho de 1926, no salão Pio XI, do Asylo S. Rita, pela Liga Catholica em commemoração ao $1^{\circ}$ Centenário do Bispado de Cuiabá). Revista do Instituto Histórico e Geográfico de Mato Grosso, Cuiabá, Anno VIII, Tomo XVI, p. 37-55, $1926 \mathrm{c}$.

CORREAA, D. Francisco de Aquino. Salve, Pátria! No "Dia da Pátria”, em Campo Grande (MS). 7 de setembro de 1939. In: SILVA, Corsíndio Monteiro da (Org.). Dom Francisco de Aquino Corrêa - Discursos. Brasília: Imprensa Nacional, 1985h. v. 2. p. 225-229.

CORREAA, D. Francisco de Aquino. Terra Natal - Versos. Rio de Janeiro: Imprensa Nacional, 1940b. 
CORRÊA, D. Francisco de Aquino. Terra Natal. Revista do Instituto Histórico e

Geográfico de Mato Grosso, Cuiabá, Anno I, Tomo I, p. 17-48, 1919 d.

CORRÊA, D. Francisco de Aquino. Terra Natal. Revista do Instituto Histórico e Geográfico de Mato Grosso, Cuiabá, Anno I, Tomo II, p. 95-143, 1919 e.

CORRÊA, D. Francisco de Aquino. Terra Natal: versos a Mato Grosso, o grande Estado do Oeste Brasileiro. Rio de Janeiro: Imprensa Nacional, 1949.

CORREAA, D. Francisco de Aquino. Um almirante mato-grossense. Elogio fúnebre do Contra-Almirante João Batista das Neves, em solenes exéquias na Capela do Liceu Salesiano. Cuiabá, 23 de janeiro de 1911. In: SILVA, Corsíndio Monteiro da (Org.). Dom Francisco de Aquino Corrêa - Discursos. Brasília: Imprensa Nacional, 1985c. v. 1, p. 25-37.

CORRÊA, Philogônio de Paula. Discurso. (Proferido pelo orador official, $1^{\circ}$ secretário do Instituto). Revista do Instituto Histórico e Geográfico de Mato Grosso, Cuiabá, Anno I, Tomo II, p. 7-11, 1919.

ESTATUTOS DO INSTITUTO HISTÓRICO DE MATTO-GROSSO. Revista do Instituto Histórico e Geográfico de Mato Grosso. Anno I, Tomo I, p. 8-14, 1919.

FAVERO, Luigi. As cartas pastorais de D. Francisco de Aquino Corrêa: apresentação histórica e idéias pastorais. Campo Grande: [s. n.], 1996.

FLEIUSS, Max. D. Aquino. In: CORRÊA, D. Francisco de Aquino. Centenário do bispado de Cuiabá no Rio de Janeiro. Rio de Janeiro: [s.n.], 1926.

GALETTI, Lylia da Silva Guedes. Nos confins da civilização: sertão, fronteira e identidade nas representações sobre Mato Grosso. São Paulo, 2000. Tese (Doutorado em História) - Faculdade de Filosofia, Letras e Ciências Humanas, Universidade de São Paulo.

GALVÃO, Benjamin Franklin Ramiz. Resposta do Dr. B. F. Ramiz Galvão ao discurso de D. Aquino. In: CORREAA, D. Francisco de Aquino. Centenário do bispado de Cuiabá no Rio de Janeiro. Rio de Janeiro: [s. n.], 1926.

LEOTTI, Odemar. Instituto Histórico e Geográfico de Mato Grosso - IHGMT: relações de poder, escrita, política, cientificidade e a invenção do mato-grossense moderno (1895 a 1934). São Paulo, 2013. Tese (Doutorado em História) - Faculdade de Ciências e Letras de Assis. Universidade Estadual Paulista.

LIVROS NOVOS - "TERRA NATAL" - D. AQUINO CORREA - ESCOLA TYPOGRAPHICA SALESIANA, DE NITEROY. O Imparcial, Rio de Janeiro, ano XV, 30 set. 1926, n. 05690, p. 4. Disponível em:

<http://memoria.bn.br/DocReader/DocReader.aspx?bib=107670_02\&PagFis=28311 >. Acesso em: 06 jun. 2017.

Horizonte, Belo Horizonte, v. 16, n. 50, p. 780-811, maio/ago. 2018 - ISSN 2175-5841 
MARIN, Jérri Roberto. Dom Francisco de Aquino Corrêa e a criação de uma unidade moral e nacional para os mato-grossenses. In: MARIN, Jérri Roberto. Religiões,

religiosidades e diferenças culturais. Campo Grande: UCDB, 2005. p. 59-73.

NA ACADEMIA BRASILEIRA, COMO SERÁ RECEBIDO HOJE NO PETIT TRIANON O NOVO IMORTAL, D. AQUINO CORRÊA. O Imparcial, Rio de Janeiro, ano XVI, n. 02900, p. 5, 30 nov. 1927. Disponível em:

<http://memoria.bn.br/DocReader/DocReader.aspx?bib=107670_02\&PagFis=33363>. Acesso em: 19 abr. 2016

NORA, Pierre (Dir.). Les lieux de mémoire. Paris: Quarto Gallimard, 1997. v. 2.

O CENTENARIO DO BISPADO DE CUYABÁ: A RECEPÇÃO DO SR. D. AQUINO CORREAA NO INSTITUTO HISTORICO GEOGRAPHICO BRASILEIRO. Rascunhos. O Imparcial, ano XV, n. 05634, p. 10, 27 jul. 1926. Disponível em:

<http://memoria.bn.br/DocReader/DocReader.aspx?bib=107670_02\&PagFis=27691>. Acesso em: 06 jun. 2017.

OLIVEIRA VIANNA, Francisco José de. Evolução do povo brasileiro. Rio de Janeiro: Companhia Editora Nacional, 1938.

PRADO, Cesario. D. Aquino. In: CORRÊA, D. Francisco de Aquino. Centenário do bispado de Cuiabá no Rio de Janeiro. Rio de Janeiro: [s. n.], 1926.

RASCUNHOS. O Imparcial, Rio de Janeiro, ano XV, n. 05662, p. 2, 27 ago. 1926.

Disponível em:

<http://memoria.bn.br/DocReader/DocReader.aspx?bib=107670_02\&PagFis=28311>. Acesso em: 5 jun. 2017.

ZORZATO, Osvaldo. Alicerces da identidade mato-grossense. Revista do Instituto

Histórico e Geográfico Brasileiro, Rio de Janeiro, ano 161, p. 419-436, jul./set, 2000. 